\title{
A PAIXÃO MILITANTE; OS ESCRITOS DE HANNAH ARENDT SOBRE O EU REVOLUCIONÁRIO
}

\author{
The militant passion; Hannah Arendt's writings on \\ the revolutionary self
}

\author{
Marion Brepohl*
}

\begin{abstract}
RESUMO
Partindo de excertos sobre temas como "revolução", "classe trabalhadora", "engajamento" e "promessa", analisados nos livros e artigos de Hannah Arendt, pretendo refletir sobre a figura do eu-revolucionário, ilustrado pela autora em diversos momentos de seu trabalho.

Trata-se do feito extraordinário (ainda que aquele em pequena escala), realizado pelo homem comum, que se destaca devido a seu compromisso, resistência, oposição. O objetivo deste artigo é, a partir de algumas leituras de Hannah Arendt, discutir os sentimentos e sensibilidades que motivam o engajamento político, sua linguagem e dinâmica interna, tanto quanto a quase inevitável oscilação ente o desejo de liberdade e a disposição à obediência, o sincero amor à causa e a tendência à mentira.
\end{abstract}

Palavras-chave: militância; paixão revolucionária; Hannah Arendt; movimentos sociais; partidos; política

\begin{abstract}
Starting with the excerpts on themes like working class, revolution, engagement and promise, contained in Hannah Arendt's books and articles my purpose is to reflect on the concept of the revolutionary self, illustrated by the author in several occasions of her writings.It refers to the "extraordinary" (although small scale) accomplishment of the common man, who stands out due to his commitment, resistance, opposition.

* Professora Titular de História Contemporânea do Departamento de História da Universidade Federal do Paraná; bolsista 1C do Cnpq. E-mail: mbrepohl@yahoo.com.br
\end{abstract}


The goal of this article is to discuss, folowing some reflections of Hannah Arendt, the feelings that motivate political commitment, its language and internal dynamics, as well as the almost inevitable oscillation between the desire of freedom and the disposition to obedience, between the sincere love for the cause and the tendency to lie.

Keywords: militancy; revolutionary passion; Hannah Arendt; social movements; parties; politics

Mundos do trabalho, resistência à disciplina, greves, protestos, associações, tantas são as temáticas suscitadas a partir dos movimentos operários. Principalmente, mas não só, a historiografia inglesa de inspiração marxista, com uma densa leitura de Antonio Gramsci, orientou as pesquisas de diversos historiadores. No Brasil, a apropriação desta literatura se deu em uma conjuntura de extrema importância, pois coincidiu com o retorno à normalidade institucional e a criação do Partido dos Trabalhadores.

Neste e em diversos outros países, principalmente a partir dos movimentos de 1968, a conexão aparentemente indissolúvel classe/sindicato/partido foi sendo colocada em dúvida, abrindo espaço para outros questionamentos e arranjos políticos que envolviam os conflitos entre capital e trabalho (Garrido, 2015).

Muito frequentemente, neste contexto, estimularam-se estudos que passaram a problematizar os movimentos sociais em sua pluralidade e suas especificidades, quando não, suas divergências internas. Daí derivaram diversos aportes teóricos, dos quais ressalto os subaltern studies, protagonizados, entre outros, por Ranajit Guha (2009). Esta corrente, a partir dos conceitos gramscianos de hegemonia e contra-hegemonia, propõe uma combinação entre o marxismo e categorias próprias dos nativos (Balestrini, 2013). Importante citar ainda os estudos pós-coloniais, os estudos de gênero, as análises sobre formas de resistência no cotidiano, a cultura popular que são, entre outros, desdobramentos das primeiras análises. E eu me 
detenho aqui, não por desconsiderar outras correntes, mas para não desvirtuar-me do tema a que me proponho.

Este artigo pretende retomar a experiência da militância da classe trabalhadora a partir dos escritos de Hannah Arendt, principalmente aquela desenvolvida pelos movimentos de esquerda de orientação marxista. Pretensiosa ambição; afinal, o que ainda não foi dito a este respeito? Mais estranho ainda pode soar a associação do tema a Hannah Arendt, a quem se atribui, muitas vezes, o estigma de elitista, em virtude de suas críticas a Karl Marx que, segundo a autora, definiu o homem como animal laborans, submetendo, com isto, a política ao reino da necessidade e atraindo as massas ao espaço público em nome de seus interesses privados. ${ }^{1}$

$\mathrm{Na}$ contracorrente da crítica marxista, e consciente que esta, dada a sua densidade, mereceria outro artigo, o que pretendo neste artigo bibliográfico é lançar o desafio de acompanharmos a autora em suas considerações sobre a paixão militante, suas possibilidades de criação de momentos de liberdade, ou seja, a ação política, bem como chamar a atenção para os riscos inerentes à organização hierarquizada que a moldura.

\section{Arendt e o engajamento político}

As energias afetivas que envolvem ações coletivas de esquerda são semelhantes, mas não uniformes. Os movimentos sociais, desde a Revolução Francesa até a queda do muro de Berlim, como nos ensina Hobsbawm (1989), tinham como ideário comum a esperança revolucionária. Tinham também seus líderes e seus projetos, definidos com programas e táticas de ação.

Esta ética pode ser ilustrada com os seguintes exemplos:

1 Sobre a redução do homem moderno ao estatuto de animal laborans, ver CORREIA, 2013. Sobre a crítica à divisão entre o econômico e o político na teoria da ação arendtiana, ver: HOBSBAWM, 1973 e HABERMAS, 1980. 
O modo habitual de procedimento nessas reuniões semanais era o seguinte. O presidente (cada homem era presidente por rodízio) lia algum livro... e as pessoas presentes eram convidadas a fazer observações sobre o lido, todas as que quisessem, mas sem se levantar. Então lia-se mais um outro trecho e havia uma segunda rodada. Então lia-se o restante e fazia-se um terceiro convite, quando se esperava que os que não tinham falado antes dissessem algo. Então havia uma discussão geral.

Sociedade Londrina de Correspondência, 1771.

(Thompson, 1987: 170)

Os comunistas são, pois, na prática [praktisch], o sector mais decidido, sempre impulsionador, dos partidos operários de todos os países; (...) O objetivo mais próximo dos comunistas é o mesmo do que o de todos os restantes partidos proletários: formação do proletariado em classe, derrubamento da dominação da burguesia, conquista do poder político pelo proletariado.

Manifesto do Partido Comunista, Londres, $1847 .^{2}$

El bien más preciado es la libertad

hay que defenderla con fe y valor.

Alza la bandera revolucionaria

que llevará al pueblo a la emancipación.

En pie pueblo obrero, ;a la batalla!

hay que derrocar a la reacción.

Hino da Confederação Nacional do trabalho, Espanha, $1936 .^{3}$

Aquí se queda la clara,

La entrañable transparencia,

2 Disponível em http//www.pcp.pt/manifesto-do-partido-comunista-edições-avante1997. Pesquisa realizada em julho de 2016.

3 Apud SIMÕES, Dulce. Memórias e canções da Guerra de Espanha. Disponível em http://www.academia.edu/2592815/memórias_e_canções_da_Guerra_de_Espanha_1936-1939.

Pesquisa realizada em Agosto de 2016. 
De tu querida presencia

Comandante Che Guevara.

(...)

Tu amor revolucionario

Te conduce a nueva empresa

Donde esperan la firmeza

De tu brazo libertario (...).

Hasta siempre comandante Che Guevara, $1998 .^{4}$

Eu poderia multiplicar os exemplos de elaborações estéticas que atravessam a história do movimento operário, mais particularmente, de movimentos sociais animados pelo ato revolucionário, definido por Arendt "como abertura e momento de incandescência do político no qual a história se abre à liberdade da ação" (1988:23). São manifestos, hinos e poesias compostos com palavras emocionadas que não cessam de conclamar o povo ao ativismo e à participação.

Trata-se predominantemente da militância de esquerda. Independentemente de suas variantes, alguns denominadores comuns precisam ser ressaltados: a ânsia por libertação e por igualdade, o engajamento, a crença na possibilidade, necessidade $e$ irreversibilidade da história, a esperança na felicidade pública.

É a partir desta ideia-força que Arendt se inspira para redigir seu livro, "Da revolução", publicado originalmente em 1963, no período próximo à publicação de a "Condição Humana" (1958) e "Entre o Passado e o Futuro" (1961).

Segundo Enégren (1984), estes três livros significam uma tentativa, da parte da autora, de reconciliação com o mundo, e apontam para experiências ou instituições que seriam capazes de enfrentar o deserto provocado pelo totalitarismo. Para a Arendt, o oásis seria a política, entendida não como administração ou governo, mas a política como ação plural entre os diferentes e divergentes partícipes do espaço público.

4 Wilson, R. A. Jr. PUEBLA, C. 1998. Hasta siempre comandante Guevara. Disponível em https://www.letras.mus.br/carlos-puebla/235419/. 
Dado meu objetivo, tomemos primeiramente o livro "Da revolução", um ensaio cujo tema é a revolução a partir de dois casos, a Revolução Francesa e a Revolução Americana, tendo como pano de fundo o socialismo soviético.

Trata-se de um texto muito criticado entre os historiadores de profissão: a pouca relevância conferida ao trabalho escravo nos Estados Unidos no momento mesmo da proclamação da independência e da fundação da república; a tentativa de dividir o poder econômico do poder político, distinguindo-os em "esfera do social" e esfera do poder decisório ou consultivo (Aguiar, 2014); a pouca consideração dispensada a outras experiências revolucionárias, como China e Cuba, por exemplo (Hobsbawm, 1985).

Como historiadora, também tenho reservas a este livro, afinal, a própria tradição de conselhos locais se origina de movimentos sociais de pessoas mais pobres que, embora orientadas pelo primado do reino da necessidade, não tinham como único objetivo ordenar seu mundo exclusivamente pelos imperativos da vida material, conforme sugere a autora (Arendt, 1988: 70). Há uma excessiva idealização da experiência norte-americana; dentre outras questões, ressalte-se, a pouca problematização do sistema escravista nos Estados Unidos e a vigência do sistema bicameral que foi uma forma de tratar de forma desigual os cidadãos. O livro parece mais um ensaio que constrói um tipo ideal de revolução do que um estudo ancorado na historiografia sobre o tema.

No entanto, não quero me deter nestes aspectos. Meu objetivo é refletir sobre os sujeitos privilegiados da revolução - a figura do $e u-$ revolucionário, analisado pela autora em diversos de seus escritos.

A expressão $e u$-revolucionário não se traduz como uma identidade essencializada, atributo de um sujeito idealizado como herói, com características extraordinárias. Adoto tal expressão como imagem de um "eu" que é ao mesmo tempo "nós", como cidadãos que, em suas relações intersubjetivas produzem, pela vontade, um novo acontecimento em seu mundo (Heuer, 2009).

Segundo Habermas, a propósito da ação movida pelas convicções comuns: 
É fascinante observar como H. Arendt percebe em diferentes ocasiões o mesmo fenômeno. Quando os revolucionários se apropriam do poder que está nas ruas; quando a população que optou pela resistência passiva enfrenta tanques estrangeiros, com mãos desarmadas; quando minorias convictas disputam a legitimidade das leis existentes e organizam a resistência civil; quando no movimento de protesto dos estudantes, o "puro desejo de ação" se manifesta - em todos esses momentos parece confirmar-se a tese de que "ninguém possui verdadeiramente o poder; ele surge entre os homens que atuam em conjunto, e desaparece quando eles novamente se dispersam (...) Esse conceito enfático da práxis é mais marxista que aristotélico; Marx o denominava "atividade crítico-revolucionária" (1980, p. 107-108).

Por outro lado, o "eu" revolucionário pode refletir um comportamento massificado e uniformizado, resultante de uma ação que, embora não diretamente coercitiva, resta petrificada pela ideologia e pela orientação do "chefe" (ARENDT, 1978, p. 580 e ss.). Neste caso, a obediência, e não a liberdade conforma as atitudes e os sentimentos.

Tendo em vista estas oscilações, detenhamo-nos, primeiramente, na ação revolucionária, que chamou a atenção de Arendt por ser identificada como ato fundador por excelência. Ela enseja o extraordinário, realizado pelo homem comum (como também, bem-entendido, pela mulher), que se destaca em virtude de seu compromisso, militância, resistência, oposição. Este herói que parece surgir do futuro para transformar o presente, ao chegar, enfrenta um, para ele, estranho topoi: o passado, a causalidade, o conformismo.

Para quem o presente é a preparação e o futuro a consumação, o ativismo o consome: quer agir, quer poder, tem coragem e imaginação. É um herói que aspira a liberdade, mas no entanto está preso, já que necessita do grupo "para que sua revolta se transforme em ação" (Arendt, 2003: 163). Sobretudo, e esta é a finalidade mesma da política; segundo Arendt, desde Roma Antiga aos nossos dias, o herói precisa prometer. Necessita entrar em cena 
com palavras, num palco bem visível e com audiência. Ali, faz a promessa (Arendt, 2008).

O comportamento militante, seja aquele manifesto individual ou coletivamente, suscitou a atenção de Arendt, ela mesma, militante em organizações sociais de resistência judaica e esposa e parceira intelectual de Heinrich Blücher, militante do Partido Comunista de Oposição da Alemanha (KPO). Mesmo quando no exílio, Blücher prosseguiu sua atuação com um grupo denominado "Conciliadores" (Die Versöhnlergruppe), com o objetivo de formar quadros para as esquerdas e combater os fascismos (Bielefeld, 2012). Graças à influência de Blücher, Arendt aprendeu a interessar-se por política e a admirar a possibilidade da revolução, sua organização espontânea, criativa e, pelo menos no início, emergindo de baixo para cima. Sobretudo, chamou-lhe positivamente a atenção a estruturação dos movimentos sociais a partir da organização de poderes locais - o que reflete a dispersão dos poderes - "o poder de todos contra um" (Arendt, 1973: 121).

Por outro lado, seus escritos sobre o perfil de Robespierre e sobre as massas enragées, ${ }^{5}$ explicitados em "Da revolução" e, em outro texto, intitulado "Da violência", (1973), fazem-me crer que Arendt nutria certa prudência, até algum temor pelo ethos militante. Sim, porque o "modelo" Robespierre é o da ação em nome do amor pelo povo, amor que se transformou em bondade absoluta, a qual, por sua vez, ao negar-se à argumentação, transformou-se em seu outro segundo a autora, o mal ilimitado (1988: 48 e ss.). De semelhante forma, considera a apologia à violência de alguns segmentos do movimento estudantil da geração de 1968, notadamente de jovens inspirados em Mao Tsé Tung, Jean Paul Sartre e Frantz Fanon, muito mais uma reação irrefletida à democracia representativa (francamente em crise) e ao armamentismo do que um compromisso com mudanças concretas em seus respectivos países (1973, p. 105-115).

5 Estamos conscientes de que Hannah Arendt não foi uma estudiosa da trajetória de Robespierre, tampouco do grupo social que lhe dispensava apoio e lhe conferia legitimidade. Dele, a autora extrai um exemplo de militante, quase de maneira literária, para refletir sobre a paixão pela causa, que se traduz no ativismo radical. Disserta também, em diversos momentos, sobre os riscos da intromissão das paixões na política, principalmente quando associada ao poder político institucional. A este respeito, ver: Roviello, 1987. 
As razões da simpatia, prudência e temor da autora ao ethos militante me fazem concluir pela ambiguidade dos movimentos sociais irrigados por tais sentimentos: de um lado, opera-se a resistência - portanto, situa-se num contra-poder, e, por outro, deseja o poder, de preferência, o poder sobre o futuro, que se opera, na maioria dos casos, pela governamentalização. É sobre este paradoxo que pretendo tratar a seguir.

\section{O militante contra o poder}

Inicio minhas considerações sobre a ética da resistência que, conforme Odílio Aguiar, realiza-se no agir. "Resistir, mais do que reagir, assumir um lugar passivo diante das forças de destruição, é fundar. A reação é o lugar da impotência e da violência, a fundação é o lugar da potência e da criatividade" (2004: 252).

Todavia, de onde deriva a ética da resistência? Encontro algumas respostas nas reflexões expostas no livro "A vida do espírito", (1991), em especial, as considerações de Arendt sobre o querer, experiência que se situa entre a razão e o desejo.

A autora afirma que a vontade é uma capacidade adquirida da mente, ou seja, não é inata ao homem, tal como o desejo e a razão. Esta capacidade, segundo a autora, traduzida na vontade de fazer, de mudar, de contestar é filha da teologia. E não de qualquer teologia, mas exclusivamente da teologia cristã, em virtude da percepção de que Deus, ao criar e ao redimir o homem, o fez (o faz) por sua vontade. Isso se encontra nos textos bíblicos desde o livro de Gênesis até os Evangelhos, quando Jesus, também por sua vontade convida os homens para segui-lo, se quiserem. Entretanto, o que é aparentemente irônico, somente com o processo de secularização, a partir do Renascimento é que a vontade se desloca do campo religioso e se generaliza como motivadora da ação, no campo secular.

Certamente, a faculdade do querer, que Arendt denomina como "ego volitivo", já encontrava suas raízes na Antiguidade Clássica. Contestando Platão, que julgava os desejos como cegos e 
incontroláveis, Aristóteles identificava outro desejo que não aquele voltado ao apetite, o desejo de aparência de excelência na polis (Arendt, 1991: 202). Contudo, tal experiência - participação e não participação à polis, parece ainda muito presa a uma decisão de caráter eminentemente racional.

Com Paulo Apóstolo, observamos outra ambiguidade de caráter religioso: a vontade de submissão voluntária, ato de converterse a Cristo sem qualquer imposição. No entanto, como a vontade humana se inclina para o mal, fica-se à mercê da graça divina. ${ }^{6}$

Poderia multiplicar as menções da autora sobre a teologia cristã e seu contributo à emergência da vontade como fenômeno coletivo, mas prefiro deter-me nas reflexões do monge franciscano Duns Scotus (?-1308) citado por Arendt. Segundo ele, se Deus criou o homem do nada (diferentemente do que professam as crenças orientais, para quem a criação é resultado da emanação) e o criou à sua semelhança, pela sua vontade, também o homem aprende a agir não pela razão, mas pela vontade. A vontade não pode ser confundida nem com intelecto nem com desejo, e mais: a vontade tem ou pode ter primazia sobre ambos. Que vontade? Aquela que recusa a fatalidade enquanto tal. Por isto, o ego volitivo

compraz-se consigo mesmo - condelectari sibi - a ponto de o "eu quero" antecipar um "eu posso"; o eu-quero-eeu-posso é o prazer da vontade.

Quanto a este aspecto [...] a habilidade que a vontade tem de tornar presente o ainda não, é exatamente oposta à lembrança. A lembrança tem uma afinidade natural com o pensamento: todo o pensamento, como dissemos, é um re-pensar (1991: 214).

Assim sendo, enquanto o ego pensante é sereno e silencioso (retiramo-nos do mundo quando pensamos), o humor do ego volitivo é impaciente, inquieto e preocupado.

6 Epístola de Romanos 7:15: Realmente, não consigo entender o que faço: pois não pratico o que quero, mas faço o que detesto. Bíblia de Jerusalém, 2006. p. 1977. 
Dadas estas características, com todos os riscos implícitos em tais procedimentos que, de resto, são raros, o extremo do ego pensante seria o absoluto quietismo, e o extremo da vontade o ativismo militante, pois em resumo, "a vontade sempre quer fazer algo, menosprezando assim implicitamente o pensamento puro cuja atividade depende totalmente de "não fazer nada" (1991: 214). O ativismo militante sorve da alegria entusiasmada por "estar realizando" e da indignação pelo objeto de sua revolta, ainda que em suas motivações subjetivas também esteja presente o senso de dever.

Retornemos, mais uma vez, a Duns Scotus. Para ele, até pode ser muito difícil para o homem não aceitar o que a razão dita, mas isso não é impossível. É como se seu intelecto o advertisse contra a precipitação, pois somos sempre inclinados a aceitar as evidências. Também é fato que resistir ao desejo seja extremamente difícil todavia não é impossível. É como se seu desejo o advertisse contra a frustração.

Por via de consequência, nem o desejo, ou seja, as paixões, que também são carências - que nos impulsionam a agir para evitar a dor, sendo assim uma necessidade de nosso apetite, nem o intelecto, que aspira ao conhecimento da verdade, equiparam-se à vontade. Pois a paixão nos arrebata, tanto quanto pode nos abandonar. E o intelecto pode recusar ou confirmar uma verdade, mas nada faz com ela, senão quando esta verdade é de algum proveito para o seu trabalho ou o seu labor. ${ }^{7}$ Já a vontade é autônoma e livre, sorve do intelecto e do desejo para colocar-se em movimento.

Conforme Arendt, Scotus estabelece uma distinção nítida entre vontade e desejo, porque somente a vontade não é transitória. Um prazer inerente à vontade em si mesma é tão natural para a vontade quanto entender e conhecer o são para o intelecto (1991: 293). Seguindo tal reflexão, Scotus nos sugere a emergência de um fenômeno novo que se espraiaria até a atualidade: primeiro, a percepção da contingência (contra o fatalismo e a causalidade), uma vez que os homens passam a almejar e a contar com o inesperado, o

7 Não é demasiado lembrar que, para Hannah Arendt, trabalho e labor são atividades efêmeras e associadas à necessidade. Já a ação pressupõe agir no mundo para construir algo inteiramente novo. A este respeito ver: (Arendt, 1983: 90 e ss.). 
inusitado, novos acontecimentos e novas instituições; segundo, que a vontade é que move os homens, e por isso, ela também é poder; um poder que não se compreende como dominação, mas como capacidade, fortaleza, vigor, coragem; terceiro, que a vontade não depende de fins pré-determinados, mas é uma inclinação que proporciona prazer no agir em si mesmo; e, finalmente, que a vontade nasce e mantém toda autonomia e liberdade na interioridade do ser, daí a singularidade de cada indivíduo e a pluralidade da ação.

Prosseguindo com estas reflexões, não deixa de ser curioso que, conquanto a vontade tenha se cristalizado a partir da teologia e da vivência devocional, é somente após o processo de secularização que ela passa a permear a mentalidade coletiva, traduzida pela ética de resistência ou pela desobediência civil.

Dúvida, senso de missão, oposição, resistência, participação, tantas são as atitudes que podem refletir o ânimo das sociedades (pelo menos, as europeias) desde a Primeira Modernidade. Mas é o pensamento (sentimento?) revolucionário que melhor ilustra este movimento de negação da fatalidade e de ansiedade pela mudança; reside aí a abertura para a transformação e a auto-transformação.

\section{$O$ militante e o poder}

Feitas estas breves considerações sobre a vontade como propulsora da resistência ativa, característica do mundo moderno, dedico-me agora a pensar as relações do militante com o poder.

Para tanto, levo em conta as reflexões de Hannah Arendt sobre o movimento operário. Contrariamente ao que muitos de seus críticos comentam, a autora não destrata o movimento como eminentemente preocupado com a esfera do social, o que o colocaria na condição de uma mera instância de representação de interesses privados. Neste tocante, Arendt procura distinguir a dinâmica dos partidos políticos, mesmo aqueles derivados dos sindicatos operários, e aquela que pode ser observada nos conselhos populares. 
O livro A condição humana foi escrito na década de cinquenta do século $\mathrm{XX}$, período em que ocorre a desradicalização ideológica dos partidos no Ocidente, atribuída ao Wellfare State keynesiano. Dada a intervenção cada vez mais pronunciada do Estado na esfera do social, as utopias revolucionárias arrefeceram em nome da utopia reformista, cedendo às negociações que implicassem em melhor distribuição da renda. Tal redirecionamento político, conquanto os razoáveis ganhos nos níveis de vida, levou ao arrefecimento da capacidade transformadora da própria história por parte desta classe social.

Já no que se refere ao período que se estende desde 1848 até 1956, com a revolução húngara, o que os operários fizeram foi alargar o espaço público, promovendo uma igualdade de desiguais que precisam ser igualados, condição para a participação política. Menos pelo que falavam e queriam, sua mera presença foi surpreendente por reivindicar liberdade e justiça para todos, logo, a democratização do poder.

\begin{abstract}
Não menos surpreendente, porém, é o papel súbito e muitas vezes extraordinariamente produtivo que os movimentos operários desempenharam na política moderna. Das revoluções de 1848 até a revolução húngara de 1956, a classe operária europeia, por ser o único setor organizado e, portanto, o principal setor da população, escreveu um dos mais gloriosos capítulos da história recente e talvez o mais promissor [ao propor] uma nova forma de governo e (...) a abolição do requisito de propriedade para o exercício do direito ao voto. (Arendt, 1983: p. 227-229).
\end{abstract}

Esta classe (segundo o conceito marxista), não se dedicava até então apenas a questões corporativas, mas à política como um todo. Segundo a autora, "as revoluções populares vêm, há mais de cem anos", pelo seu próprio modo de organização e ação, "propondo sem êxito, o sistema de conselhos populares em substituição ao 
sistema partidário continental, que já nasceu desacreditado" (Arendt, 1983: 228). ${ }^{8}$ E desacreditado por boa parcela dos próprios trabalhadores, porque os partidos, mesmo quando instituídos como representantes da classe trabalhadora, tendem a criar uma burocracia hierarquizada à semelhança da própria administração da fábrica ou do próprio poder executivo. Por mais programáticos que sejam rumo à igualdade, seu funcionamento acaba por exigir a divisão entre elite e militância. Em virtude desta, os militantes se veem diante de dois chefes, o da causa e o do mundo do trabalho (Cohen, 2013).

Uma vez conformada tal estrutura, o militante, face ao poder, fica diante de um superego duplicado - o poder dos chefes da empresa e o poder dos chefes do partido, quando não, também dos chefes de estado em países cuja legislação prevê a intermediação institucionalizada dos conflitos entre capital e trabalho.

No entanto, o partido exerceu e ainda exerce atração sobre as pessoas, quer por sua linguagem, que apela ao "povo" como um todo, quer por seus símbolos, prenhes de signos comoventes. Ao filiar-se a um partido, o indivíduo sente superar-se de sua condição ordinária, parecendo adquirir uma segunda vida, a qual percorre e transtorna todo o seu cotidiano (Monteiro, 2013; Silva, 2014; Santana, 2001).

Isto porque, segundo o historiador Pierre Ansart (1983:110), o partido não é somente o locus da ideologia. É também um aparelho afetivo, quase que uma segunda morada, na qual o reconhecimento e o diálogo são apreciados. É um "nós" fortalecido, que se coloca contra os outros, vistos como alvo de afetos negativos, motivadores de emoções violentas. A força de atração do partido não reside apenas em sua plataforma, e sim, em alguns casos, muito mais, em sua capacidade de agregar.

Este sentimento de pertença provoca uma enorme compensação para quem convive, como é o caso do trabalhador urbano industrial, com diversos sentimentos de perda: sua

8 A condição humana é um livro da década de cinquenta, e é a partir das experiências de seu tempo que Arendt redige o capítulo sobre o movimento operário. Para ela, enquanto que o movimento sindical se deixa orientar por reivindicações atinentes a questões econômicas, o movimento político dos operários ultrapassa os programas partidários de reformas econômicas, reivindicando sua emancipação política, ou seja, o exercício do poder como cidadãos de direito. Todavia, nas democracias ocidentais em que se pratica o wellfarestate, os operários sindicalizados não fazem senão defender seus interesses privados, como quaisquer outros membros da sociedade. 
propriedade, (o pequeno negócio, a terra, seu know-how), os vínculos familiares, o prestígio entre os seus.

A literatura do século XIX nos dá conta de sua angústia em face ao desemprego, o medo da miséria, o horror à solidão, a humilhação do patronato (Frevert, 2013). Por estes motivos, a pertença a um partido tende a responder a problemas afetivos vinculados à falta. Esta se deve à destruição dos vínculos tradicionais existentes no século XVIII, período em que a paróquia, a vizinhança e a família moldavam as relações de convívio.

Contudo, embora os trabalhadores encontrem no partido "seus iguais", há diferenças significativas nas funções que exercem no grupo, o que frequentemente, provoca tensões e conflitos, principalmente pela hierarquia ali instituída: o chefe nacional ou mesmo internacional, o chefe local, a diretoria, o orador, o intelectual, os deputados. A hierarquia suscita esperanças, ambições, mas principalmente, e quase nunca de maneira explícita, rivalidades (Ansart, 1983: 117).

$\mathrm{Na}$ base da pirâmide, encontra-se o militante: distribui panfletos e organiza a passeata, participa das greves como quem obedece à boa lei, sentindo que seus líderes, não impostos mas desejados, seriam os melhores governantes. Obedecer aí não é sinônimo de ser dominado, mas de participação. Por isso a importância dos jornalistas, "poetas do partido": suas palavras reforçam a identidade dos membros. Os panfletos são estetizados por eles e servem como força de persuasão afetiva tanto para o recémingresso como para o "velho" militante. Com apelos ainda mais fortes, citem-se os hinos, as bandeiras, o culto aos heróis (Monteiro, 2013: 137 e ss.).

Quanto ao chefe, é visto como alguém que não se deixa conduzir pelo prazer de exercer poder, nem somente pela satisfação de ser reconhecido, mas por encarnar o ideal dos adeptos e de ser amado por isto (...) "ele é objeto de reverência, mas carrega consigo um enorme senso de responsabilidade" (Ansart, 1983: 117).

Entre o chefe e o militante, diversas outras funções, mas a mais conflitiva é a do deputado que, conquanto obedeça ao chefe, sente-se e de fato se encontra numa função mais elevada. Sua atuação é vulnerável porque é nela que a eficácia das estratégias é posta à prova: de sua negociação depende a vitória ou a derrota. 
Dado o segredo e o compromisso que quase toda negociação exige, o representante suscita a suspeição, pois parte de seu poder reside na realização de concessões. E não raro, comete pequenas ou grandes traições aos membros do partido em nome dos fins que justificam os meios. Daí também sua tendência à mentira; as acusações de Trotsky a Stalin relativamente às suas intrigas e ambição, bem como os conluios para ocupar o lugar de Lenin, (Trotsky,1929), são exemplo daquilo que Hannah Arendt comentou sobre o homem de estado. Dissimulado e autoritário, ele fabrica uma sociedade cujo fim ele mesmo produziu. Ao proceder assim, e assim convicto de precisar agir de maneira sagaz, a classe trabalhadora não se torna senão um instrumento "de que o déspota usa e abusa" (Arendt, 2003: 80). Por essas razões, segundo Arendt, inflar o poder em nome de um fim tido como verdadeiro seja talvez mais perigoso do que inflá-lo por vaidade.

Estas são algumas razões pelas quais o militante não é convocado a falar, estando condenado às tarefas rotineiras, seja do partido, quando a figura do chefe já se pronuncia de maneira autocrática, seja nos movimentos que "animam" os governos totalitários, quando o chefe é alvo de todos os olhares da população. Nestas circunstâncias, as tarefas do militante são semelhantes àquelas realizadas na fábrica. Apesar de tudo, ele é fiel à causa, principalmente nos momentos políticos mais contundentes. Nos momentos de monótona calmaria, seu entusiasmo arrefece. Mesmo assim, ele vê tudo aquilo como um sacrifício que faz para libertar-se, a si e a sua família, principalmente seus filhos. É uma verdade histórica, um futuro certo, sem erro. A liberdade depende ironicamente de sua obediência.

Sobre esta estrutura afetiva, Ansart tece a seguinte consideração:

ao final, já no que concerne a um partido unânime e sem dissensões ou falhas, perfilam-se as grandes linhas de um regime totalitário, pois o partido desperta os vínculos, amplia a euforia do amor político, mas acha no controle 
destas emoções uma fonte de poder de seus adeptos (1983: 130).

\section{Considerações finais}

Desde 1951, quando redige o livro "Origens do totalitarismo", ao discutir o advento da sociedade de massas, Arendt, nos passos de Rosa de Luxemburg, ressaltou o declínio da representatividade dos partidos políticos, dado o distanciamento entre sua base e a elite (1978: 213). Tal enfraquecimento se deve também a sua dinâmica interna e sua linguagem: a oscilação entre a liberdade para agir e a obediência cega, a espontaneidade e a verdade científica, entre amizade e a apropriação do outro, da imaginação à mentira, da coragem à hybris.

Preocupada com o papel reservado ao militante (que pode encontrar-se num partido ou num movimento social que acaba por aproximar-se de algum partido, nem que seja episodicamente), procurei analisar as reflexões de Hannah Arendt sobre o movimento operário, que foi uma das experiências políticas mais elogiadas pela autora, dada sua capacidade de promover a igualdade entre os desiguais e por sua capacidade de ampliação da esfera pública. Fiquei atenta também às suas reservas quanto à estrutura partidária, na qual o militante acaba por tornar-se uma presa da burocracia do partido e de promessas que correspondam aos interesses imediatos do homo laborans.

Fiz este percurso com certa liberalidade, uma vez que os escritos de Arendt sobre a paixão militante encontram-se dispersos em sua obra, tanto quanto o estudo sobre as relações entre movimentos sociais, sindicatos e partidos. Mesmo não sendo seu foco central, no que se refere a estes temas, a autora apontou o risco que incorremos quando traduzimos movimento sindical por movimento político dos trabalhadores, o que leva a eleger um governo cujas

9 Tradução livre da autora 
ações se orientam para a defesa dos que se encontram no "reino da necessidade", como o fizeram os jacobinos na França e os bolcheviques na União Soviética, transformando os pobres em raison $d$ 'être do Estado e elidindo-se da esfera pública todos aqueles que fossem considerados seus "adversários".

De maneira semelhante, incorria em tal risco, segundo a autora, a esquerda do Ocidente democrático das décadas de cinquenta e sessenta do século passado que, de posse dos ensinamentos da Revolução Francesa e da Revolução Russa, prosseguia em adotar um comportamento elitista, esperando que a "massa" lhe obedecesse ou ao menos reconhecesse nela seu papel protagônico. (Arendt, 1985, p. 12 e ss.). Esta esquerda parecia chancelar e, mais arriscado ainda, parecia acreditar que fosse produtiva a máxima de Gramsci: "O elemento popular sente, mas não compreende nem sabe; o elemento intelectual sabe mas não compreende e especialmente não sente". ${ }^{10}$

Em quaisquer dos casos apontados, a paixão, em especial, pelo poder decisório, encontrava-se presente muito mais entre os chefes do que entre os governados, donde o malogro do caráter democrático da revolução.

Segundo minha compreensão, o pensamento de Arendt ainda guarda atualidade. Vivenciamos um período em que por mais sinceras que sejam as promessas dos partidos políticos que defendem a melhoria de vida dos mais pobres, enfrenta-se o obstáculo da globalização que resultou, entre outros aspectos, na perda de soberania dos governos nacionais. Hoje, há mais poder decisório nas agências internacionais (como o Banco Mundial, por exemplo), do que em programas de governos legitimamente eleitos; hoje, o poder se concentra nos imperativos do complexo financeiro-empresarial com dimensões globais; estes não se apoiam nos partidos políticos, mas naqueles que lhes garantam a supremacia do mercado e do lucro. ${ }^{11}$ Por sua vez, os partidos, com o final do socialismo soviético, a democracia competitiva e o marketing eleitoral, transformaram-se em mera ante-sala do poder executivo, a ele submetidos, como se a

10 Citado por RAGAZZANI, 2005, p. 53

11 Le monde diplomatique, 24/05/2017. http://diplomatique.org.br/13-pontos-paraembasar-qualquer-analise-de-conjuntura/. Pesquisa realizada em 16 de julho de 2017. 
disposição à obediência fosse o preço a pagar para o comando de amanhã, em qualquer cargo do departamento de estado e sem a "necessidade" de cumprir ou fazer cumprir a promessa.

Contudo, esta crise é, a meu ver, uma possibilidade de devolver ao político o lugar de onde veio: do debate, da vontade por mudanças, da luta por direitos a ter direitos (Arendt), da ação concertada e da lei (incluindo aí a lei que autoriza a desobediência civil). Sobretudo, como anteparo à violência, seja das massas despolitizadas que, uma vez experimentada a deserção cívica, aderem ao crime organizado, seja da violência praticada pelos governos em nome da ordem interna, ao que parece ter se reduzido seu papel segundo a lógica neoliberal.

Entretanto, em que pese a fragilidade dos pactos políticos tendo em vista esta nova configuração do estado, bem como a desconfiança dos programas de médio e longo prazo, a paixão militante prossegue seu trabalho. Motiva iniciativas, faz circular mensagens comoventes, destitui de legitimidade, pelo menos na imaginação, seus opositores. Entre a liberdade e a obediência, assume diversos riscos, inclusive, o de transformar-se naquilo que nega; todavia, em suas manifestações, escapa, ainda que por pouco, do horizonte restrito do mero ato de consumir e de comportar-se a contento.

\section{Referências Bibliográficas}

AGUIAR, O. 2004. A resistência em Hannah Arendt: da política à ética, da ética à política".in: DUARTE, A. LOPREATO, C. \& BREPOHL DE MAGALHÃES, M. A banalização da violência. Rio de Janeiro: Relume-Dumarà, p. 247-262.

AGUIAR, O. 2014. A questão do social em Hannah Arendt. Trans/form/ação, São Paulo, 27 (2). p. 7-20.

ANSART, P. 1983 La gestion des passions politiques. Lausanne: L 'âge d 'homme. $212 \mathrm{p}$. 
ARENDT, H.1973. Crises da república. São Paulo: Perspectiva. 201 p.

ARENDT, H. 1978. O sistema totalitário (Origens do totalitarismo). Lisboa: Dom Quixote. 622 p.

ARENDT, H. 1983. A condição Humana. Rio de Janeiro: Forense Universitária. $259 \mathrm{p}$.

ARENDT, H.1988 Da revolução. Brasília: EDUNB, 260 p.

ARENDT, H. 1991. A vida do espírito. Rio de Janeiro: Relume Dumarà. 392 p.

ARENDT, H. Denktagbuch. 2003. München: Piper Verlag, 1050 p.

ARENDT, H. 2008. A promessa na política. Rio de Janeiro: DIFEL, $283 \mathrm{p}$.

BALLESTRINI, L. 2013. América Latina e o giro decolonial. Revista Brasileira de Ciência Política, n.11. Brasília, maio - agosto, pp. 89117.

Bíblia de Jerusalém. 2006. São Paulo: Paulus, 2206 p.

BIELEFELD, U. et all. 2012. Gesellschaft, Gewalt, Vertrauen. Jan Philipp Reemtsma zum 60. Geburgstag. Hamburg. 435 p.

COHEN, Y. 2013. Le Siècle des chefs. Une histoire transnationale du commandement et de l'autorité (1890-1940), Paris: Éditions Amsterdam. $1050 \mathrm{p}$.

CORREIA, A. 2013. Quem é o animal laborans de Hannah Arendt? Revista de Filosofia Aurora. Curitiba, v. 25, n. 37, p. 199-222.

ENÉGREN, A. 1984. La pensée politique de Hannah Arendt. Paris: PUF, $345 \mathrm{p}$.

FREVERT, U. 2013. Trust as work. In: KOCKA, J. (Hrsg.) Work in a modern society. British Library Cataloguing in Publication Data, p. 56-67.

GARRIDO, F. 2015. Edward Palmer Thompson; Historia, experiência y formación para pensar la historia de la educación. 
Cuadernos Chilenos de Historia de la Educacion. N. 3. Santiago del Chile, p. 8-32.

GUHA, R. 2009. The smal voice of History.London: Permanent Black. 367 p.

HABERMAS, J. 1980. O conceito de poder em Hannah Arendt. In: FREITAG, B. \& ROUANET, S. Habermas. São Paulo: Ática. p. 100118.

HEUER, Wolfgang. 2009. Nem eu nem eles; intersubjetividade no pensamento de Hannah Arendt. In: NAXARA, M, MARSON, I. \& BREPOHL, M. Figurações do outro. Uberlândia: EDUFU. p. 157174.

HOBSBAWM, E. 1985. O conceito de revolução de Hannah Arendt. In: Revolucionários. Rio de Janeiro: Paz e Terra, p. 44-51.

HOBSBAWM, E. 1989. Adeus a tudo aquilo. In: BLACKBURN, Robin. Depois da queda; o fracasso do comunismo e o futuro do socialismo. Rio de Janeiro: Paz e Terra. P. 80-89.

Le monde diplomatique, 24/05/2017. http://diplomatique.org.br/13pontos-para-embasar-qualquer-analise-de-conjuntura/. Pesquisa realizada em 16 de julho de 2017

MONTEIRO, C. 2013. Política entre razão e sentimentos: a militância dos comunistas no Paraná (1945-47). Curitiba, PR. Doutorado. Universidade Federal do Paraná. 356 p.

RAGAZZANI, Dario. 2005. Teoria da personalidade na sociedade de massa; a contribuição de Antonio Gramsci. Rio de Janeiro: Autores Associados.

SANTANA, M. 2001. Homens partidos; comunistas e sindicatos no Brasil. Rio de Janeiro: Boitempo. 156 p.

SILVA, T. 2014. Entre sapatos e livros: a trajetória de um sapateiro na militância comunista em Paranaguá/PR - 1935 a 1964. Mestrado. Universidade Federal do Paraná. 154 p.

ROVIELLO, Anne-Marie. 1987. Senso comum e modernidade em Hannah Arendt. Lisboa: Instituto Piaget. 
THOMPSON, E. P. 1987. A formação da classe operária inglesa: A árvore da liberdade. Rio de Janeiro: Paz e Terra. 367 p.

TROTSKY, L. 1929. O triunfo de Stalin. in: New York Times. Disponível em http://www.marxists.org/portugues/trotsky/1929/02/25.htm. Pesquisa realizada em setembro de 2009.

RECEBIDO EM: 16/07/2017 APROVADO EM: 09/07/2018 